\title{
12: 11694055-11939603
}

National Cancer Institute

\section{Source}

National Cancer Institute. 12:11694055-11939603. NCI Thesaurus. Code C42223.

Physical location of ETV6_Gene 